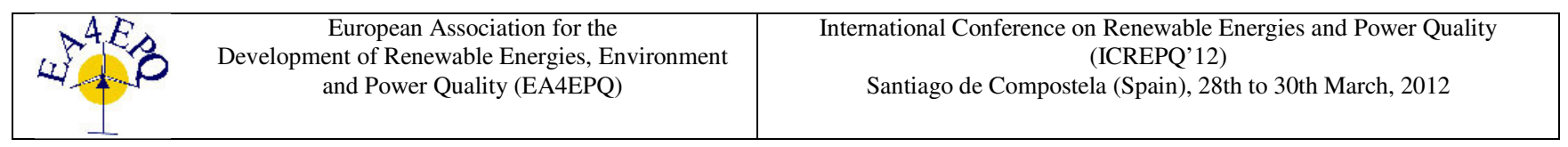

\title{
Assessment and modelling of the waste heat availability from gas turbine based CHP systems for ORC systems
}

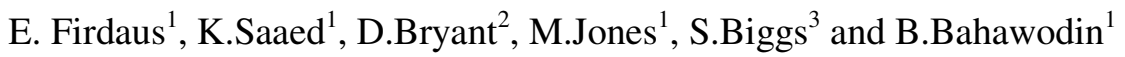 \\ ${ }^{1}$ Computing Engineering and Mathematics \\ University of Brighton \\ BN2 4GJ (United Kingdom) \\ Phone/Fax number: +0044 203 0060166/65, e-mail: E.Firdaus@brighton.ac.uk, K.Saaed@brighton.ac.uk, \\ M.P.Jones@brighton.ac.uk, B.Baha@brighton.ac.uk \\ ${ }^{2}$ Heatcatcher Ltd. \\ The Roller Mill \\ Mill Lane Uckfield \\ TN22 5AA (United Kingdom) \\ Phone/Fax number: +0044 203 0060166/65, e-mail: Darren.Bryantt@heatcatcher.com \\ ${ }^{3}$ Efficient Air Ltd. \\ The Roller Mill \\ Mill Lane Uckfield \\ TN22 5AA (United Kingdom) \\ Phone/Fax number: +0044 182 5748150/51, e-mail: Steven.Biggs@efficientair.co.uk
}

\begin{abstract}
This paper presents the findings of modelling of waste heat availability from a Combined Heat and Power (CHP) system with a rated electrical output of $4.35 \mathrm{MW}$ and steam production of $8,165 \mathrm{~kg} / \mathrm{hr}$ at $16 \mathrm{barg}$. The model has been developed using HYSYS Dynamics ${ }^{\mathrm{TM}}$. The amount of waste heat available from the CHP system is dependent on the ambient air, steam production, and gas turbine power output. A Pitot traverse measurement across the duct was undertaken to determine the actual amount of waste heat available from the CHP system. The measurements were conducted in accordance to BS EN 15259:2007 standards. The simulation results of waste heat availability have been compared to experimental data at various CHP power outputs. The HYSYS Dynamics ${ }^{\mathrm{TM}}$ model waste heat calculation was shown to be 5.3\% lower than experimental waste heat measurements. An analysis of the waste heat availability by both modelling and experiment was done which shows that the CHP system waste heat available between $3.82 \mathrm{MW}$ and 5.09 MW. Recovering this low grade heat from the CHP system using Clean $\mathrm{Cycle}^{\mathrm{TM}} 125$ ORC systems generates between $217 \mathrm{~kW}$ and $344 \mathrm{~kW}$ of electricity, respectively. Increases of $2.3 \%$ in electrical efficiency of the CHP system are predicted.
\end{abstract}

\section{Key words}

waste heat recovery; gas turbine; modelling; Hysys; CHP; ORC

\section{Introduction}

Interest in capturing low-grade (low temperature) heat has grown dramatically in past decades [1]. Important alternatives have been proposed to generate electricity from low temperature heat sources such as solar thermal power, industrial waste heat, engine exhaust gases and domestic boilers [1]-[2]. The potential for utilising waste heat from industrial applications is particularly promising [3] because of the large amount of waste heat. Statistical investigations indicate that low-grade waste heat account for $50 \%$ or more of the total heat generated in industry [4].

Using conventional methods such as steam rankine cycle to recover energy from low-grade heat is economically infeasible [5]-[6]. However, the Organic Rankine Cycle (ORC) system [1],[6],[4],[7] uses a high molecular working fluid which boils at a lower temperature than water and is thus more efficient than water with low grade waste heat. Working fluids used in the ORC system have been studied, such as R-113 [8]-[11], R-245fa [5],[12],[13], R-245ca [9]-[11], Toluene [7],[11] and Ammonia [10],[14].

A typical ORC system basically comprises a pump, a turbine, an evaporator and a condenser. The working fluid is vaporised by a heat source in the evaporator. The superheated vapour of the working fluid expands in the turbine to generate electricity and is then condensed. The condensed working fluid is finally sent via a pump into 
the evaporator thus closing the cycle. An economiser can increase the efficiency of the system by pre-heating the working fluid entering the evaporator with the heat from the working fluid leaving the evaporator (see figure 1). The biggest influences on the performance of the ORC system are the amount and temperature of the waste heat. An accurate assessment of waste heat availability is needed for optimisation of waste heat recovery.

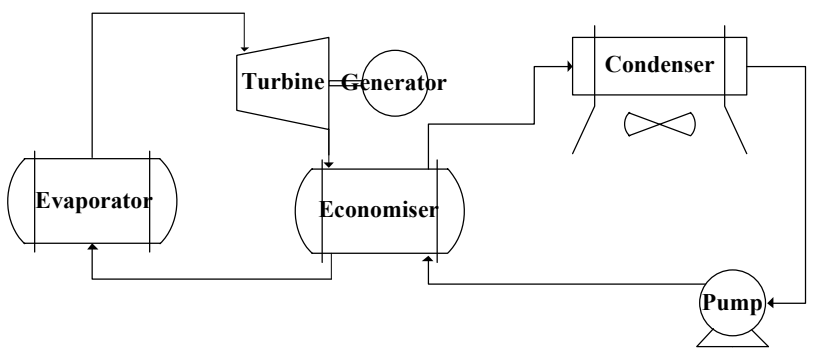

Fig. 1. Process flow diagram of ORC system integrated with an economiser.

This paper focuses on low-grade heat recovery from gas turbine based systems. Most of the modern gas turbines available in the market offer efficiencies up to $42 \%$ [17]. One important disadvantage of a gas turbine is that it does not perform well in part-load operation [17]-[19]. For instance, at $50 \%$ load, a gas turbine achieves around $75 \%$ of the full-load efficiency, and at $30 \%$ this drops to $50 \%$ of the nominal efficiency [17]. Technology has combined with gas turbines to boost the overall efficiency to more than 50\% [20]-[21]. Most of the technologies utilise the high-grade heat exhaust from the gas turbine. Table I summarises these different technologies. The low-grade heat exhausted from combined cycle can be further utilised. For instance, the temperature of exhaust gas leaving Brayton-Brayton cycle is between $200^{\circ} \mathrm{C}$ and $250^{\circ} \mathrm{C}[17]$.

This paper focuses on low-grade heat recovery from industrial Combined Heat and Power (CHP) systems, based on gas turbines in a simple-cycle (Brayton cycle) mode integrated with a waste heat steam boiler as shown in figure 2. A significant amount of heat is lost through flue gases as all the heat produced from the combustion process of the fuel is not transferred to the water/ steam in the boiler [25]. Evans reported about 10-20\% energy used in a CHP system is lost through the flue and casing [15]. There is significant benefit in utilising the low-grade waste heat from a CHP system.

Recovering waste heat from a CHP system is challenging since the amount of waste heat exhausted from the system is dependent on the upstream process. Thus, it is important to investigate the energy and amount of waste heat. The energy in waste heat is a function of mass flow rate, chemical composition, and temperature. The amount of waste heat available from a CHP system is dependent on the load of the plant.

The main objectives of this study are to:

- establish the waste heat availability from a CHP system at various ambient temperatures and outputs.
- investigate the feasibility of integrating an ORC system with a CHP system.

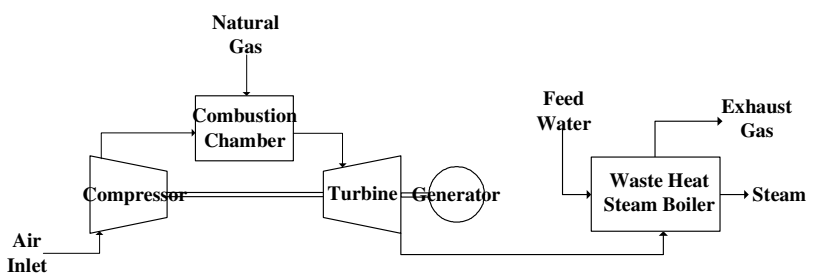

Fig. 2. Simplified process flow diagram of CHP systems based on gas turbine in simple-cycle (Brayton cycle) mode integrated with waste heat steam boiler.

Table I. Summary of different combined cycles integrated with gas turbine.

\begin{tabular}{|l|l|c|}
\hline $\begin{array}{l}\text { Combined } \\
\text { cycle/Technology }\end{array}$ & \multicolumn{1}{|c|}{ Gas turbine model } & $\begin{array}{c}\text { New } \\
\text { overall } \\
\text { efficiency }\end{array}$ \\
\hline $\begin{array}{l}\text { Gas to gas } \\
\text { recuperation } \\
\text { cycle }\end{array}$ & $\begin{array}{l}\text { 1.4 MW Heron [22] } \\
\text { 21 MW Rolls-Royce [23] }\end{array}$ & $\begin{array}{c}39-43 \% \\
42 \%\end{array}$ \\
\hline $\begin{array}{l}\text { Brayton-rankine } \\
\text { cycle }\end{array}$ & $\begin{array}{l}\text { W501G } \\
\text { Siemens/Westinghouse [24] } \\
\text { GT24 and GT26 ABB- } \\
\text { Alstom[24] }\end{array}$ & $58 \%$ \\
General Electric & $58.5 \%$ \\
\hline $\begin{array}{l}\text { Brayton-brayton } \\
\text { cycle }\end{array}$ & $\begin{array}{l}\text { Allison 571 K [17] } \\
\text { LM2500 General Electric }\end{array}$ & $43.2 \%$ \\
\hline $\begin{array}{l}\text { Brayton-Stirling } \\
\text { cycle }\end{array}$ & RB211 Rolls Royce & $47.7 \%$ \\
\hline $\begin{array}{l}\text { Chemical } \\
\text { recuperation } \\
\text { cycle }\end{array}$ & LM5000PC General Electric & $45 \%$ \\
\hline Cheng cycle & $\begin{array}{l}\text { M1A-13CC KAWASAKI } \\
\text { Heavy Industries } \\
\text { 501-KII Allison Engine } \\
\text { Company } \\
\text { LM5000 General Electric }\end{array}$ & $33.7 \%$ \\
\hline
\end{tabular}

\section{Methodology}

A CHP system is modelled based around the following subsystems: a combustion chamber, a gas turbine and a waste heat boiler. The simplified flow diagram of the CHP system is presented in figure 2. A software based model of the CHP system was developed using HYSYS Dynamics $^{\mathrm{TM}}$ integrates all concepts and considerations. The actual measurements of the exhaust gas were conducted using a Pitot tube in order to determine the actual temperature and flow rate of the exhaust gas. Historic performance records of the CHP system from 2007 to 2009 were used in order to investigate the waste heat availability from the CHP system.

\section{A. Process simulation}

The gas turbine engine under consideration in this study is an industrial, simple cycle gas turbine engine consisting of an axial flow compressor, combustion chamber and axial flow turbine. The simulation model of the gas turbine system, integrated with waste heat steam boiler was developed using HYSYS Dynamics ${ }^{\mathrm{TM}}$ software. The CHP system is composed of a $4.35 \mathrm{MW}$ gas turbine (model SGT-100-1S) and a waste heat steam boiler with a rated capacity of $8,165 \mathrm{~kg} / \mathrm{hr}$ at $16 \mathrm{barg}$. The 
process flow drawing in the HYSYS Dynamics ${ }^{\mathrm{TM}}$ simulator is shown in figure 3 .

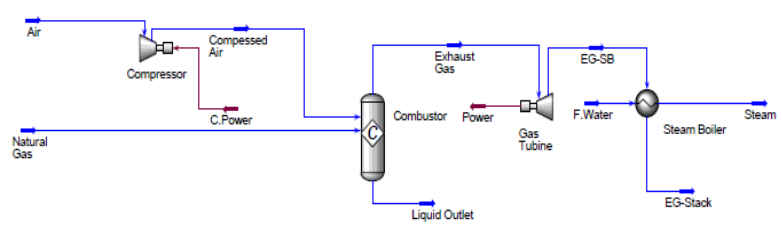

Fig. 3. HYSYS Process Flow Diagram for CHP systems

1) Simulation Data. The technical simulation data of the 4.35 MW CHP systems is shown in table II.

Table II. Gas Turbine (Model SGT-100-1S) and waste heat steam boiler principal data at ambient temperature $5^{\circ} \mathrm{C}$.

\begin{tabular}{|l|c|c|}
\hline Gas Turbine & & \\
\hline Heat Input & $\mathrm{kW}$ & 15,213 \\
\hline Heat Rate & $\mathrm{kJ} / \mathrm{kW} . \mathrm{h}$ & 11,810 \\
\hline Generator Output & $\mathrm{kW}$ & 4,637 \\
\hline Speed of Gas Turbine & $\mathrm{Rpm}$ & 16,500 \\
\hline Pressure Ratio & & 13.0 \\
\hline Turbine Inlet Temperature & ${ }^{\circ} \mathrm{C}$ & 1,054 \\
\hline Turbine Outlet Temperature & ${ }^{\circ} \mathrm{C}$ & 522.6 \\
\hline Air Flow & $\mathrm{kg} / \mathrm{s}$ & 18.38 \\
\hline Compressor Exit Pressure & $\mathrm{bar}(\mathrm{a})$ & 13.29 \\
\hline Steam Boiler & & \\
\hline Steam Production & $\mathrm{kg} / \mathrm{hr}$ & 8,165 \\
\hline Pressure & $\mathrm{bar}(\mathrm{g})$ & 16 \\
\hline Exhaust Gas Analysis & & \\
\hline Oxygen & $\mathrm{wt} \%$ & 16.17 \\
\hline Nitrogen & $\mathrm{wt} \%$ & 74.24 \\
\hline Water Vapour & $\mathrm{wt} \%$ & 3.67 \\
\hline Carbon Dioxide & $\mathrm{wt} \%$ & 4.64 \\
\hline Argon & $\mathrm{wt} \%$ & 1.25 \\
\hline
\end{tabular}

2) Stoichiometric combustion. Stoichiometric air has to be supplied to ensure complete combustion of the fuel in the gas turbine [10]. Methane is specified as the fuel in the CHP system. Equation 1 shows the chemical reaction in the combustion chamber of the CHP system

$$
\mathrm{CH}_{4}+2\left(\mathrm{O}_{2}+3.76 \mathrm{~N}_{2}\right) \rightarrow \mathrm{CO}_{2}+2 \mathrm{H}_{2} \mathrm{O}+7.52 \mathrm{~N}_{2}
$$

\section{B. Experiment Measurements}

A physical experiment determined the volumetric velocity and temperature of the exhaust gas. The instrumentation used was an S-type Pitot tube with a K-type thermocouple.

1) Experiment Rig. The measurements were performed using a 9-point traverse grid, in accordance with BS EN 15259:2007 standard. Figure 4(a) shows the dimension and measurement points across the duct. Figure 4(b) shows the CHP systems arrangements and the location of measurements. The measurements were undertaken on the roof top of the boiler house at the proposed location for waste heat recovery systems using ORC technology. The process parameters from the CHP system such as fuel consumption, gas turbine power output, exhaust gas temperature from gas turbine and steam production were also monitored.

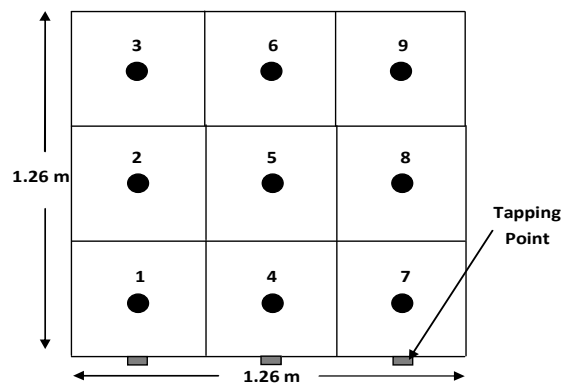

Fig. 4(a). Measurement grid according to BS EN 15259:2007 Standard

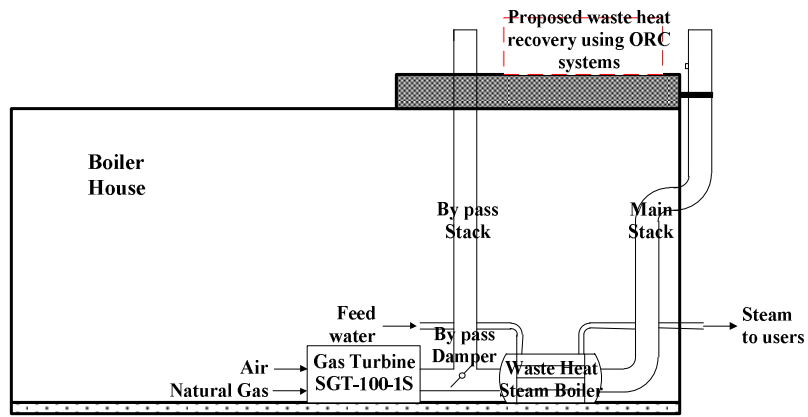

Fig. 4(b). Measurement points and proposed location for waste heat recovery systems.

2) Point Velocity Equation. The general relationship between the velocity of the exhaust gas and the pressure caused by the exhaust gas moving over the Pitot tube (total pressure minus static pressure) is given by equation 2 [9].

$V=4.72136 K_{\text {pitot }} \Gamma_{\text {pitot }} \sqrt{h_{k p a} / d}$

where

$\mathrm{V}$ exhaust gas velocity $(\mathrm{m} / \mathrm{s})$

$\mathrm{K}_{\text {pitot }} \quad$ Pitot tube constant

$\Gamma_{\text {pitot }} \quad$ gas compression constant

$\mathrm{h}_{\mathrm{kPa}} \quad$ [total pressure - static pressure] $(\mathrm{kPa})$

d exhaust gas density $\left(\mathrm{kg} / \mathrm{m}^{3}\right)$

Equation 2 can be simplified by substituting the Pitot tube constant $\left(\mathrm{K}_{\text {pitot }}=0.84\right)$ and if the velocity of the exhaust gas over the Pitot tube is limited to subsonic velocities, the gas compression constant $\left(\Gamma_{\text {pitot }}\right)$ is equal to 1. If these parameters are followed, the point velocity equation can be simplified by equation 3 .

$V=3.966 \sqrt{h_{k p a} / d}$

The density of the exhaust gas can be calculated using equation 4.

$d=3.4834 G P / Z T$

where 
absolute temperature (Kelvin)

compressibility factor of exhaust gas

\section{Waste Heat Analysis}

A significant amount of heat is lost through the flue gases as all the heat produced from the combustion process of the gas turbine cannot be transferred to water or steam in the waste heat steam boiler. Therefore, recovering the heat from the exhaust gas can help to improve the total efficiency of the CHP system. Heat can be recovered from the flue gas by passing it through a heat exchanger that is installed after the boiler [10] or using an Organic Rankine Cycle (ORC) machine to produce electricity from the low grade waste heat [11]-[12]. The amount of waste heat available (sensible heat) can be expressed as:

$Q=m C_{p} \Delta T$

where

$\mathrm{m} \quad$ mass flow of flue gas $(\mathrm{kg} / \mathrm{s})$

$\mathrm{C}_{\mathrm{p}} \quad$ specific heat of flue gas $(\mathrm{kJ} / \mathrm{kg} . \mathrm{K})$

$\Delta \mathrm{T} \quad$ temperature drop of flue gas $\left({ }^{\circ} \mathrm{C}\right)$

\section{Recovering Waste Heat using ORC Systems}

The amount of waste heat recovered depends on the properties of the working fluid of the ORC system. This research focuses on using Clean Cycle $^{\mathrm{TM}} 125$ ORC systems to recover the waste heat. The technical specifications of the Clean Cycle $^{\mathrm{TM}} 125$ ORC systems are shown in table III.

Table III. Technical specifications of Clean Cycle ${ }^{\mathrm{TM}} 125$ ORC Systems[29]

\begin{tabular}{|l|c|}
\hline Working fluid & $\mathrm{R}-245 \mathrm{fa}$ \\
\hline Electrical output gross & $125 \mathrm{~kW}$ \\
\hline Evaporation temperature of refrigerant & $121^{\circ} \mathrm{C}$ \\
\hline Input energy & $980 \mathrm{~kW}$ \\
\hline
\end{tabular}

\section{Results}

\section{A. HYSYS Simulation}

The results of the simulation model were based on clean performances of the CHP systems:

1) Waste Heat Analysis at Various Ambient Temperatures. Figure 5(a) and 5(b) show the influence of ambient air temperature on the exhaust gas flow rate and exhaust gas temperatures leaving the gas turbine and waste heat boiler. The ambient air temperature has strong influence on the performance of the gas turbine [26]-[27]. The net power output from the gas turbine decreases with the increase of ambient air temperature [28]. At an ambient air temperature of $-5^{\circ} \mathrm{C}$, the flow rate of the exhaust gas is $19.2 \mathrm{~kg} / \mathrm{s}$ and the temperature of the exhaust gas from the gas turbine is $494^{\circ} \mathrm{C}$, and $219^{\circ} \mathrm{C}$ leaving the waste heat boiler. As the ambient air temperature increases to $25^{\circ} \mathrm{C}$, the exhaust gas flow rate decreases to $16.6 \mathrm{~kg} / \mathrm{s}$ and the temperature from the gas turbine increases to $542^{\circ} \mathrm{C}$, and $228^{\circ} \mathrm{C}$ leaving the waste heat boiler.

2) Waste Heat Analysis at Various Steam Production Rate. The fluctuation of steam demand from the site will affect the grade and quantity of the waste heat from the waste heat boiler. Figure 6(a) and 6(b) show the results of simulation of waste heat analysis from the waste heat boiler at various steam production and ambient temperatures. The simulation was done at a constant gas turbine power output, 4.35 MW. At $100 \%$ steam production, the amount of waste heat available from the CHP system is $4.62 \mathrm{MW}$ at an ambient temperature of $-5^{\circ} \mathrm{C}$. At $52 \%$ steam production, the amount of waste heat available is $7.36 \mathrm{MW}$. At an ambient temperature of $25^{\circ} \mathrm{C}$, the amount of waste heat available is between $3.62 \mathrm{MW}$ and $6.36 \mathrm{MW}$ at $100 \%$ and $52 \%$ steam production respectively. The temperature of the exhaust gas varies between $219^{\circ} \mathrm{C}$ and $381^{\circ} \mathrm{C}$.

3) Waste Heat Analysis at Various Gas Turbine Output. Figure 7(a) shows the influence of the gas turbine output on exhaust gas conditions. At 2.3 MW gas turbine output, the flow rate of the exhaust gas is $18.19 \mathrm{~kg} / \mathrm{s}$ and the temperature from the gas turbine is $490^{\circ} \mathrm{C}$. The analysis was done at constant steam output, $8,165 \mathrm{~kg} / \mathrm{hr}$ and ambient temperature of $5^{\circ} \mathrm{C}$. Figure 7(b) shows the analysis of the exhaust gas temperature and amount of waste heat from the waste heat boiler. At 2.3 MW gas turbine output, the temperature of the waste heat is $201{ }^{\circ} \mathrm{C}$ with $3.82 \mathrm{MW}$ of energy available. The temperature of the exhaust gas from the waste heat boiler increases as the gas turbine output increases.

\section{B. Pitot Tube Measurements}

The results of the Pitot Tube measurements are shown in figure 8 below. Figure 8(a) shows the temperature and mass flow profiles of the exhaust gas at a gas turbine power output of $2.3 \mathrm{MW}$. At $2.3 \mathrm{MW}$ gas turbine power output, the average flow rate of the exhaust gas is 19.7 $\mathrm{kg} / \mathrm{s}$ and average temperature of $214^{\circ} \mathrm{C}$. The amount of waste heat rate available is $4.50 \mathrm{MW}$. This is based on an ambient temperature of $5^{\circ} \mathrm{C}$. At higher load (figure 8(b)), 4.35 MW gas turbine power output, the amount of waste heat rate available is $5.13 \mathrm{MW}$. This is based on an average flow rate of $19.8 \mathrm{~kg} / \mathrm{s}$ and average temperature of exhaust gas of $242^{\circ} \mathrm{C}$.

\section{Waste Heat Availability Analysis}

The analysis of the amount of energy exhausted from the stack is shown in figure 9. The analysis was done based on historical data of the performance of the CHP system: gas turbine power output, steam production, ambient 
temperature, fuel consumption, operating hours and average monthly ambient temperature of the site location. The amount of waste heat available from the CHP system varies between $3.82 \mathrm{MW}$ and 5.09 MW.

\section{Recovering Waste Heat using ORC Systems}

The viability of recovering waste heat using ORC systems is dependent on the amount of waste heat and the temperature of the heat source. The amount of waste heat available and power generation from the CHP system was calculated based on an exit exhaust gas temperature of $125^{\circ} \mathrm{C}$ and ORC system efficiency of $12.75 \%$. The amount of waste heat available from the CHP system varies between 1.70 MW and 2.70 MW (see figure 10(a)). Transforming this waste heat using ORC systems (Clean Cycle $^{\mathrm{TM}} 125$ ) could generate between $217 \mathrm{~kW}$ and $344 \mathrm{~kW}$ of gross electricity, see figure 10(b).

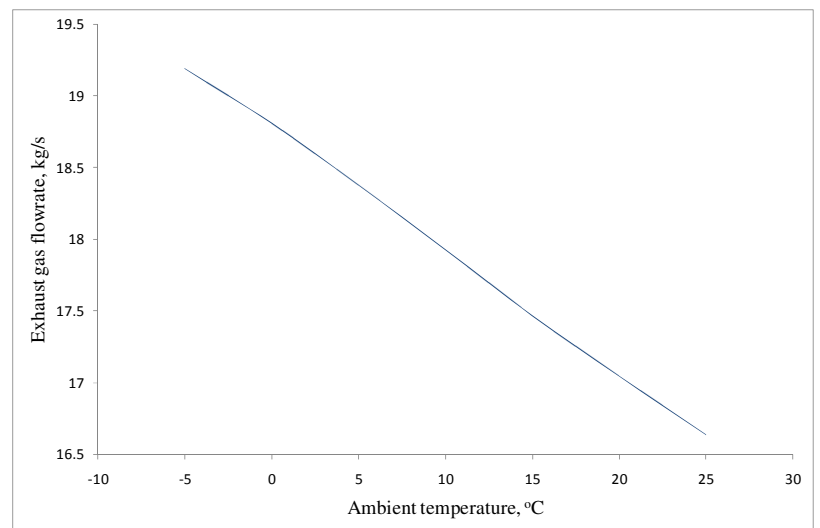

Fig. 5(a). The effect of ambient air temperature on the exhaust gas flow rate.

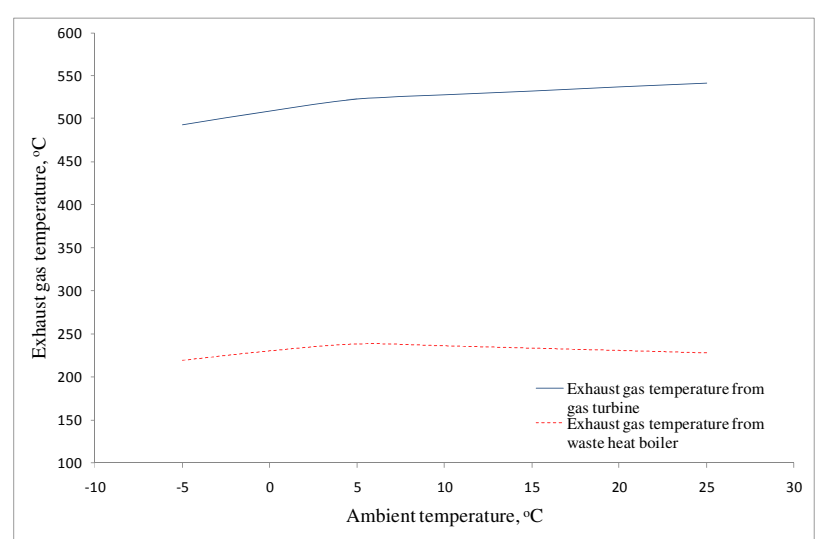

Fig. 5(b). The effect of ambient air temperature on the exhaust gas temperature from gas turbine and waste heat boiler.

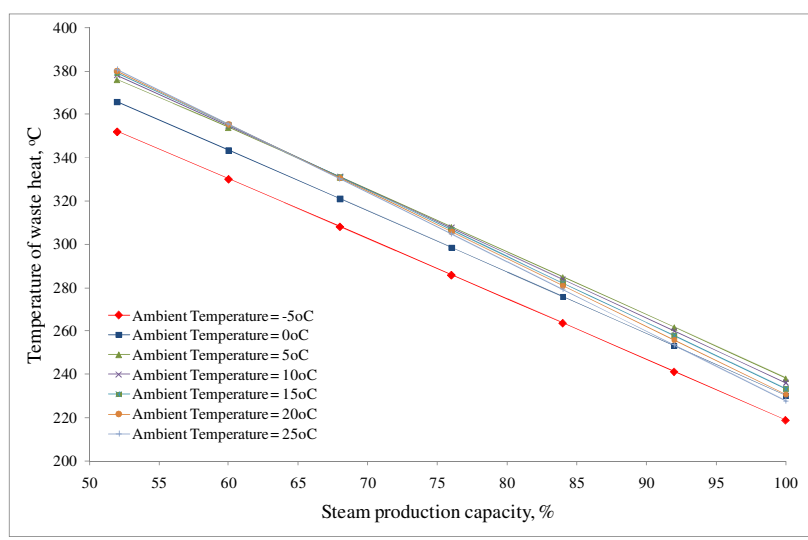

Fig. 6(a). Influence of steam production on the exhaust gas temperature at various ambient temperatures.

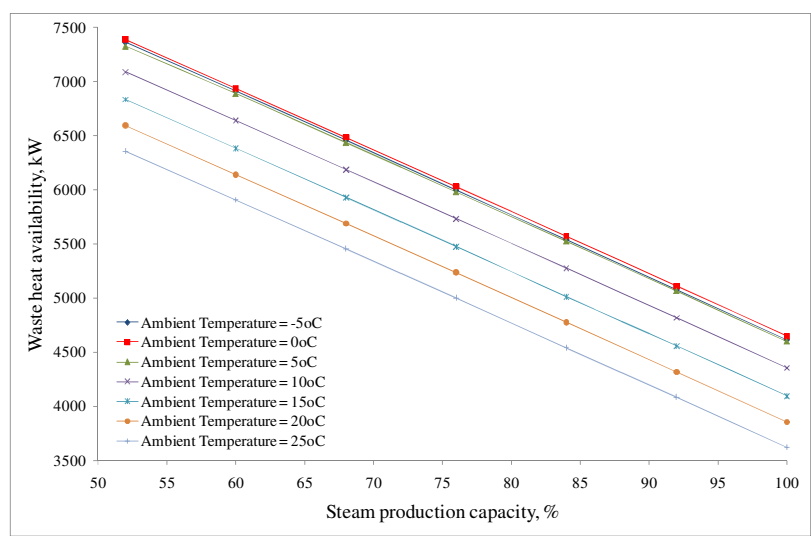

Fig. 6(b). Influence of steam production on the energy available from the exhaust at various ambient temperatures.

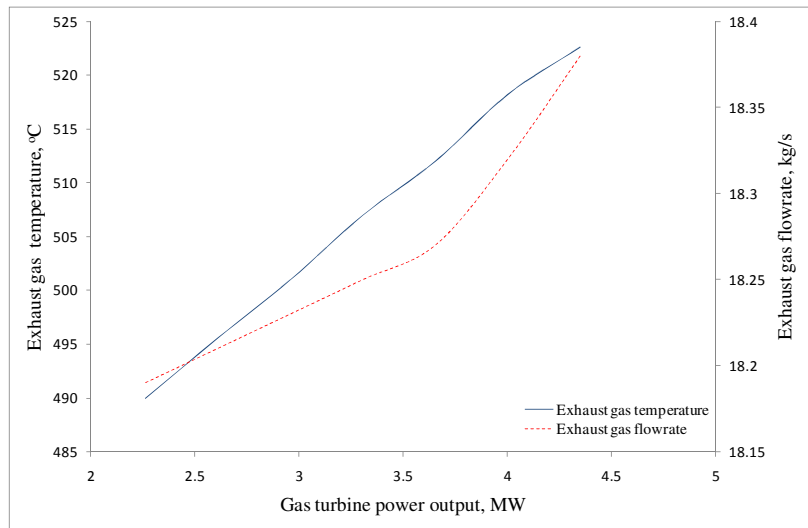

Fig. 7(a). Exhaust gas conditions from the gas turbine at various gas turbine output.

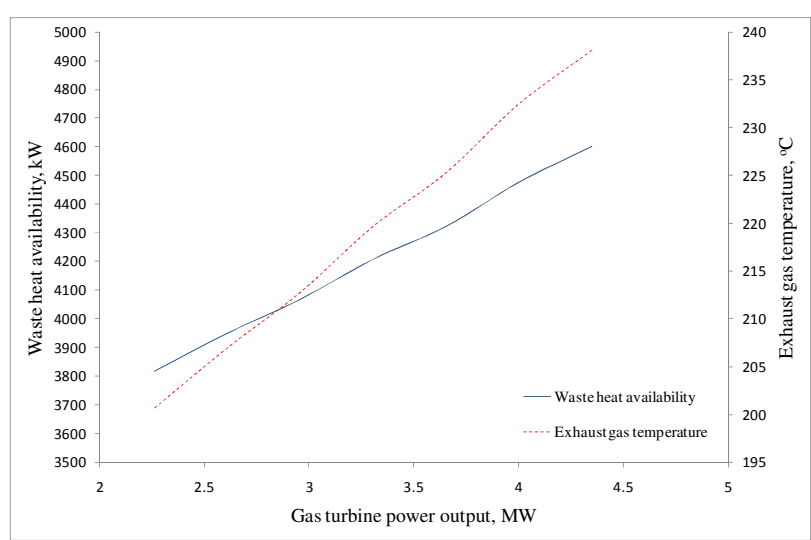

Fig. 7(b). Exhaust gas conditions from the waste heat boiler and energy available at various gas turbine output. 


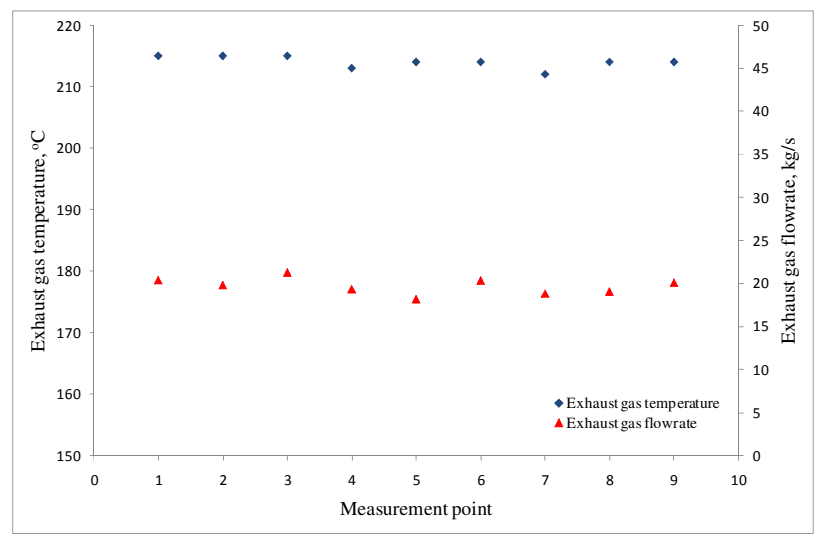

Fig. 8(a). Temperature and flow profiles across the duct of exhaust gas for CHP output of $2.3 \mathrm{MW}$

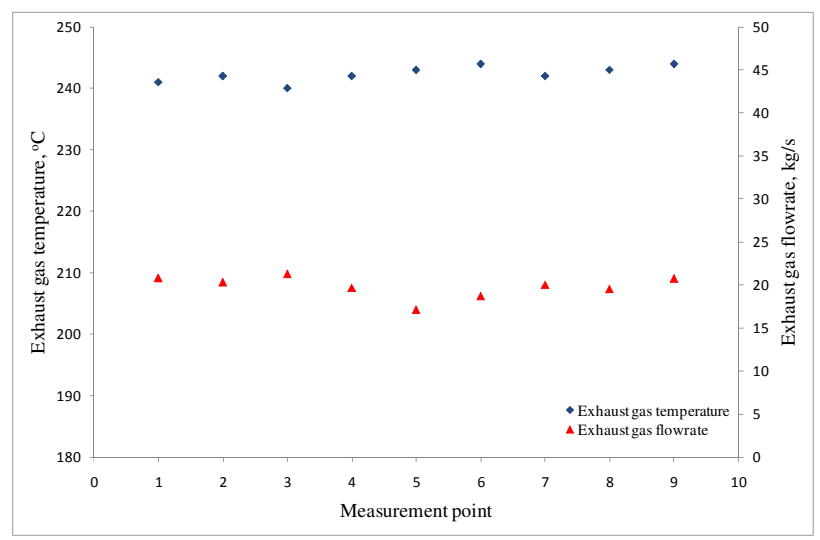

Fig. 8(b). Temperature and flow profiles across the duct of exhaust gas for CHP output of $4.35 \mathrm{MW}$

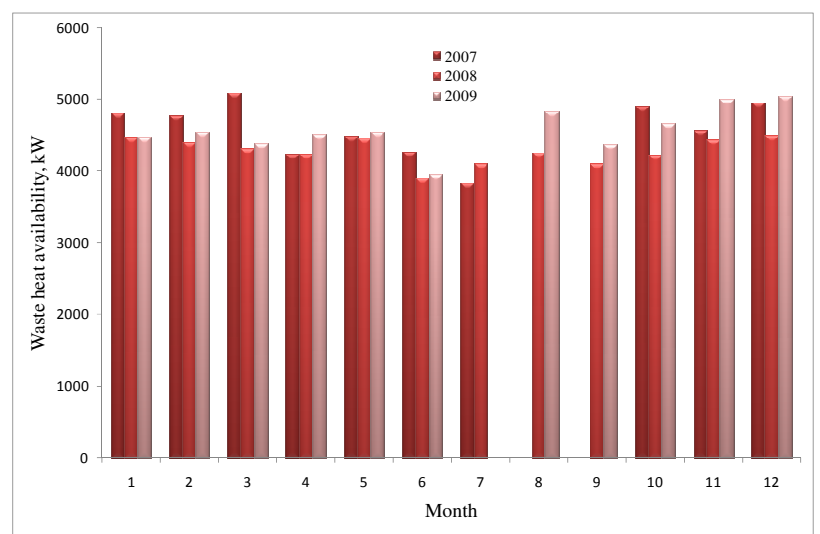

Fig. 9. Analysis of waste heat availability exhausted from the CHP systems from 2007-2009.

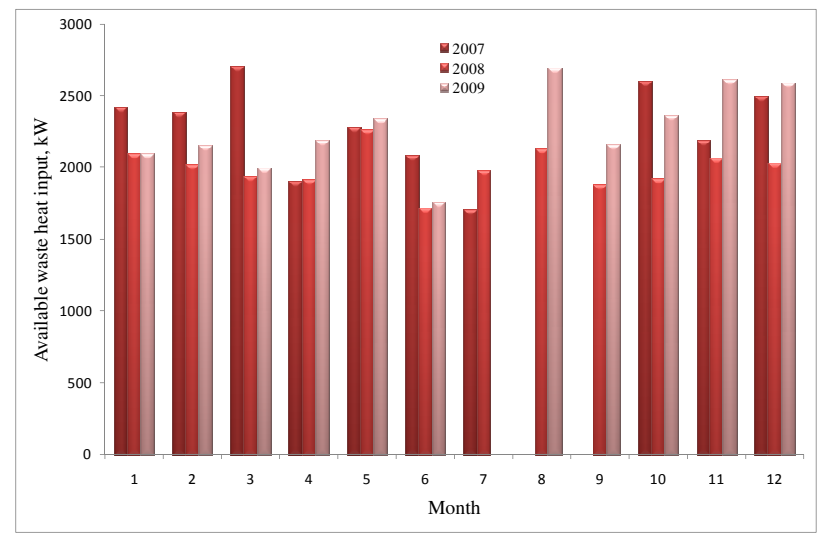

Fig. 10(a). Availability of waste heat to be utilised using Clean $\mathrm{Cycle}^{\mathrm{TM}}$.

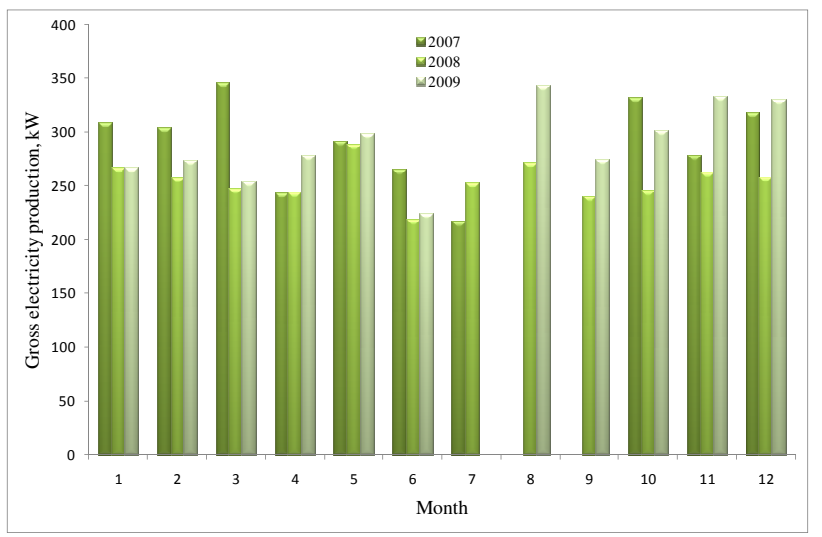

Fig. 10(b). Projection of electricity generation using ORC systems, Clean Cycle ${ }^{\mathrm{TM}} 125$.

\section{Discussion}

The simulation results show the amount of waste heat is dependent on ambient air temperature, steam production capacity and gas turbine output. The net power output from the gas turbine directional proportional to the exhaust gas mass flow rate. At lower ambient temperature, the density of the ambient air is increases. If the air mass flow rate decreases, due to the increment of ambient air temperature, the fuel input has to be reduced in order to avoid exceeding the hot gas limit temperature when entering the turbine [30], this makes the pressure ratio drop, which affect the gas turbine power output.

There is a direct relationship between the amount of waste heat available and the steam production. During low steam demands, optimum waste heat is available from the CHP system. The proposed waste heat recovery system will utilise the waste heat and maintain the efficiency of the CHP system.

At a gas turbine power output of $4.35 \mathrm{MW}$, the amount of waste heat energy predicted from the simulation is 4.86 MW and temperature is $238^{\circ} \mathrm{C}$. Based on the physical experiment conducted, the amount of waste heat energy available from the CHP system is $5.13 \mathrm{MW}$. The $5.3 \%$ difference between these values is due to the following factors:

- the simulation is based on clean performance of a CHP system whilst the actual CHP is less efficient and creates more waste heat due to fouling in the waste heat boiler.

- the actual gas turbine efficiency is less than the simulation due to changes in blade surfaces due to erosion or fouling, and the effect on the blade dynamics.

The amount of waste heat from the CHP system between 2007 and 2009 varies between 3.82 MW and 5.09 MW. Only $44.5 \%$ of the waste heat can be recovered using the Clean Cycle $^{\mathrm{TM}} 125$ ORC systems. This is due to the evaporation temperature of the R-245fa used in the ORC systems. Recovering the waste heat from the CHP system could generate between $217 \mathrm{~kW}$ and $344 \mathrm{~kW}$ gross electricity. The proposed waste heat recovery systems 
would enhance the electrical efficiency of the CHP system by $2.3 \%$.

\section{Conclusion}

The model developed through the HYSYS Dynamics ${ }^{\mathrm{TM}}$ software shows the influence of the ambient air temperature, steam production capacity and gas turbine power output on the amount of waste heat available. The model developed through the HYSYS Dynamics ${ }^{\mathrm{TM}}$ software only predicted clean performances of the CHP system. However, from the validation shown, the result matches well with the experimental values. Finally, this model should be useful as a basis to investigate waste heat availability from a CHP system.

\section{Acknowledgement}

This research is the result of a Knowledge Transfer Partnership Programme between Heatcatcher Ltd/ Efficient Air Ltd and University of Brighton.

\section{References}

[1] S.Quoilin, S.Declaye, B.F.Tchanche, V.Lemort, Thermoeconomic optimization of waste heat recovery Organic Rankine Cycles, Applied Thermal Engineering 31(2011) 19

[2] H.Chen, D.Y.Goswami, E.K.Stefanakos, A review of thermodynamic cycles and working fluids for the conversion of low-grade heat, Renewable and Sustainable Energy Reviews 14(2010) 3059-3069

[3] J.Wang, Y.Dai, L.Gao, Exergy analyses and parametric optimizations for different cogeneration power plants in cement industry, Applied Energy 86(2009) 941-948

[4] T.C.Hung, T.Y.Shai, S.K.Wang, A review of Organic Rankine Cycles (ORCs) for the recovery of low-grade waste heat, Energy 22(1997) 661-667

[5] D.Wei, X.Lu, Z.Lu, J.Gu, Pefrormance analysis and optimization of organic Rankine cycle (ORC) for waste heat recovery, Energy Conversion and Management 48(2007) 1113-1119

[6] G.Pei, J.Li, Y.Li, D.Wang, J.Li, Construction and dynamic test of a small-scale organic rankine cycle, Energy 36(2011) 3215-3223

[7] B.T.Liu, K.H.Chien, C.C.Wang, Effect of working fluids on organic Rankine cycle for waste heat recovery, Energy 29(2004) 1207-1217

[8] O.Badr, P.W.Ocallaghan, S.D.Probert, Rankine-cycle systems for harnessing power from low-grade energysources, Applied Energy 36 (1990) 263-292

[9] P.J.Mago, L.M.Chamra, K.Srinivsan, C.Somayaji, An examination of regenerative Rankine Cycle using dry fluids, Applied Thermal Engineering, 28(2008) 998-1007

[10] Y.P.Dain, J.F.Wang, L.Gao, Parametric optimization and comparative study of organic Rankine cycle (ORC) for low grade waste heat recovery, Energy Conversion and Mangement 50 (2009) 576-582

[11] N.B.Desai, S.bandyopadhyay, Process integration of Organic Rankine Cycle, Energy 34 (2009) 1674-1686

[12] A.Borsukiewicz-Gozdur, W.Nowak, Comparative analysis of natural and sythetics refrigerants in application to low temperature Clausius-Rankine Cycle, Energy 32 (2007) 344-352

[13] I.H.Aljundi, Effect of dry hydrocarbons and critical point temperature on the efficiencies of organic Rankine cycle, Renewable Energy 36 (2011) 1196-1202

[14] H.D.M.Hettiarachchia, M.Golubovic, V.M.Worek, Y.Ikegami, Optimum design criteria for an Organic Rankine Cycle using low-temperature geothermal heat sources, Energy 32 (2007) 1698-1706

[15] R.Evans, Environmental and economic implications of small-scale CHP, Energy Policy (1993) 79-91

[16] T.C.Hung, Waste heat recovery of organic Rankine cycle using dry fluids, Energy Conversion and Management, 42 (2001) 539-553

[17] A.Poullikkas, An overview of current and future sustainable gas turbine technologies, Renewable and Sustainable Energy Reviews, 9 (2005) 409-443

[18] F.Haglind, Variable geometry gas turbines for improving the part-load performance of marine combined cycles Combined cycle performance, Applied Thermal Engineering, 31 (2011) 467-476

[19] Y.S.H.Najjar, Gas turbine cogeneration systems: a review of some novel cycles, Applied Thermal Engineering, 20 (2000) 179-197

[20] Y.S.H. Najjar, Efficient use of energy by utilising gas turbine combined cycle, Applied Thermal Engineering, 21 (2001) 407-438

[21] A.L.Polyzakis, C.Koroneos, G.Xydis, Optimum gas turbine cycle for combined cycle power plant, Energy Conversion and Management, 49 (2008) 551-563

[22] A.Poullikkas, Implementation of distribution generation technologies in isolated power systems, Renewable and Sustainable Energy Reviews, 11 (2007) 30-56

[23] T.Heppenstall, Advanced gas turbines cycle for power generation: a critical review, Applied Thermal Engineering, 18 (1998) 837-846

[24] A.Franco, C.Casarosa, On some perspective for increasing the efficiency of combined cycle power plant, Applied Thermal Engineering, 22 (2002) 1501-1518

[25] R.Saidur, J.U.Ahamed, H.H.Masjuki, Energy, exergy and economic analysis of industrial boilers, Energy Policy, 38(2010) 2188-2197

[26] Y.S.H Najjar, Enhancement of performance of the gas turbine engines by inlet air cooling and cogeneration system, Applied Thermal Engineering, 16(1990) 163-173

[27] M.M.Alhazmy, Y.S.H.Najjar, Argumentation of gas turbine performance using air coolers, Applied Thermal Engineering, 24(2004) 415-429

[28] Q.M.Jaber, J.O.Jaber, M.A.Khawaldah, Assessment of power augmentation from gas turbine power plants using different inlet air cooling systems, Jordan Journal of Mechanical and Industrial Engineering, 1(2007) 7-15

[29] http://www.geheatrecovery.com/wpcontent/uploads/factsheet_HRS_E_2_screen_110124.pdf [accessed 18/01/2012]

[30] A.A.Amell, F.J.Cadavid, Influence of relative humidity on the air cooling thermal load in gas turbine power plant, Applied Thermal Engineering , 22(2002) 1529-1533 